\title{
TEORIA DA ATIVIDADE, PRODUÇÃO DE SIGNIFICADO E \\ INTERDISCIPLINARIDADE COMO SUSTENTÁCULO A UMA \\ POSSÍVEL IDEIA DE EDUCAÇÃO ETNOMATEMÁTICA
}

RODOLFO CHAVES ${ }^{1}$

Instituto Federal do Espírito Santo

E-mail: rodolfochaves20@gmail.com

Vera LuCIA ANIOLA FerRarI

Secretaria Estadual de Educação do Rio Grande do Sul

E-mail: veralucia_aniolaferrari@yahoo.com.br

PATRÍCIA SILVA RODRIGUES

Universidade Federal de Santa Maria

E-mail: paty.05.05@hotmail.com

MAÍSA IORA

Universidade Federal de Santa Maria

E-mail: maisaioraa@gmail.com

\section{RESUMO}

Este texto decorre de trabalhos de: extensão a partir de um Projeto do Pibid; pesquisa de pósdoutorado junto à EEEF Arroio Grande e ao PPGEFEM-CCNE-UFSM, financiado pela Capes; ensino, a partir das práticas desenvolvidas em conjunto com a regente da classe de alunos em que atuamos. Apresentamos percursos ao desenvolvimento de atividades, pautados nos princípios de uma possível educação etnomatemática, apresentando fragmentos dos níveis de funcionamento de atividades, segundo Leontiev, e discutimos significados produzidos pelos atores à luz do Modelo do Campo Semânticos, da análise de similaridades/convergências de enunciações, verificando como esses significados interferiram na produção de conhecimento dos atores no viés de ações diferenciais, a partir da sistemática de ações, nos moldes proposto em Chaves (2000, 2004, 2005), consolidados a partir de um processo político, sócio histórico, cultural, dotado de intencionalidade, operacionalidade, com motivos claros, tendo como elementos de sustentação, pelo menos uma necessidade e algumas motivações.

${ }^{1} \mathrm{O}$ autor realizou seu estágio de pós-doutorado no PPGEFEM-CCNE, da Universidade Federal de Santa Maria. 


\title{
PALAVRAS-ChAVE:
}

Teoria Da Atividade, Produção De Significado, Educação Etnomatemática, Interdisciplinaridade, Modelos Dos Campos Semânticos.

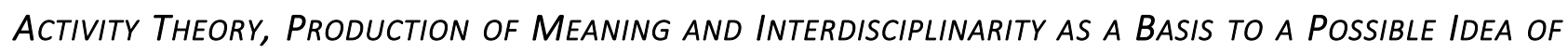
ETHNOMATEMATIC EDUCATION.

\begin{abstract}
:
This text derives from works of: extension from a Project of the Pibid; Postdoctoral research with EEEF Arroio Grande and PPGEFEM-CCNE-UFSM, funded by Capes; Teaching, based on the practices developed together with the regent of the class of students in which we work. We present paths to the development of activities, based on the principles of a possible ethnomathematical education, showing fragments of the levels of activity functioning, according to Leontiev, and we discuss meanings produced by the actors in light of the Semantic Field Model, the analysis of similarities / convergences of enunciations, Verifying how these meanings interfered in the knowledge production of the actors in the bias of differential actions, based on the systematic of actions, along the lines proposed in Chaves (2000, 2004, 2005), consolidated from a political process, historical, cultural, Endowed with intentionality, operability, with clear motives, having as elements of support, at least a need and some motivations.
\end{abstract}

\section{KEYWORDS:}

Theory Of Activity, Production Of Meaning, Ethnomatematic Education, Interdisciplinarity, Semantic Field Models.

\section{INTRODUÇÃO}

O presente texto foi construído a partir do trabalho conjunto de duas licenciandas em Matemática da Universidade Federal de Santa Maria (UFSM), um professor do curso de formação de professores de Matemática (Ifes), uma professora regente e 12 alunos que compunham a classe de 5o ano, da Escola Estadual de Ensino Fundamental (EEEF) Arroio Grande, localizada no 40 distrito do município de Santa Maria - RS, de maio a novembro de 2016. 
Nosso propósito é expor caminhos - teóricos e práticos - percorridos para o desenvolvimento de atividades, com caráter interdisciplinar ${ }^{2}$, pautados nos princípios de uma educação etnomatemática, apresentando fragmentos dos níveis de funcionamento da atividade humana (atividades propriamente ditas, ações e operações), elencados por Leontiev ${ }^{3}$, desenvolvidas no cenário exposto e, concomitantemente, discutir os significados produzidos pelo(a)s atores(atrizes) do processo - o(a)s aluno(a)s - e como esses significados interferiram na produção de conhecimento desses atores(atrizes) e na elaboração de outras práticas colaborativas cooperativas, desenvolvidas no viés de ações diferenciais ${ }^{4}$, a partir da sistemática do conjunto das ações no ciclo de discussão em grupo ${ }^{5}$, proposto em Chaves (2000, 2004, 2005), que possui um enfoque socioambiental a partir de postulados de Patrick Geddes ${ }^{6,7}$ - e consolidados a partir de um processo político,

${ }^{2}$ Consideramos que interdisciplinaridade é constituída por um grupo de disciplinas conexas e com objetivos comuns, onde ocorre intensa troca entre especialista, para estabelecer objetivos. Ações e metas comuns, focando o campo unitário do conhecimento, a negação e a superação das fronteiras disciplinares, a interação propriamente dita. (JAPIASSU, 1976).

${ }^{3}$ Alexei Nikolaievich Leontiev (1904-1979), natural de Moscou, cursou a Faculdade de Ciências Sociais da Universidade de Moscou. Foi um dos fundadores da escola da Psicologia Sócio histórica, junto a Vygotsky e Luria.

${ }^{4}$ Ação que visa alcançar os objetivos estabelecidos em grupos de pesquisa-ação para produção de materiais didáticopedagógicos (MDP) ou que leve o grupo/indivíduo a desenvolver determinada tarefa ou a refletir a respeito de sua prática ou de um tema proposto. Tal ação é consequência de uma intervenção diferencial autorregulada. Na intervenção diferencial autorregulada (intervenção na realidade por diferenciação da ação esperada dos atores) o professor intervém, em sala de aula, a partir de sua margem natural de liberdade, permanecendo como juiz de suas próprias ações, pois produz modificações neste ambiente à medida que as discute com os demais professores. (BALDINO; CARRERA DE SOUZA, 1997).

${ }^{5}$ A sistemática do conjunto de ações desenvolvidas pelo professor no ciclo de discussão em grupo sobre um problema $\leftrightarrow$ planejamento de uma ação diferencial para atacar esse problema $\leftrightarrow$ aplicação conjunta (professor + monitor/licenciando + aluno) da ação diferencial planejada $\leftrightarrow$ discussão da ação realizada $\leftrightarrow$ replanejamento. (CHAVES, 2000, p.201).

${ }^{6}$ (1854-1923), biólogo, urbanista e filósofo escocês, considerado o pai da Educação Ambiental, conhecido por seu pensamento inovador nos campos do planejamento urbano e da educação.

7 "um aluno em contato com a realidade do seu ambiente desenvolve atitudes criativas em relação ao mesmo, cabendo aos professores desempenhar o papel de interlocutores de uma educação que incorpore uma análise da 


\section{E Eebates \\ em Educação Científica e Tecnológica \\ ISSN - 2236-2150 (Eletrônica)}

sócio histórico, cultural, dotado de intencionalidade, operacionalidade, com motivos claros, tendo como elementos de sustentação, pelo menos uma necessidade e algumas motivações. Também discutimos o quão importante foi, para o trânsito do processo, adotarmos, nos moldes propostos pelo Modelo dos Campos Semânticos (MCS), as noções de: conhecimento; objeto; enunciação; produção de significado; significado; leitura plausível; autor/texto/leitor; interlocutores; espaço comunicativo; núcleo; estipulações locais; legitimidade; campo semântico.

\subsection{Um Problema a Partir de Olhares Legitimados e Chancelados Pela Academia}

É indubitável a existência do fracasso do ensino da Matemática e, portanto, dos dispositivos de controle à manutenção desse quadro. Chaves (2004) denomina o mesmo de Ensino Tradicional de Matemática (ETM) e aponta que alguns desses dispositivos são fixados ao se apresentar a Matemática de forma excludente, meritocrática, promotora de uma educação aos moldes bancários - na ótica freireana - descontextualizada e descompromissada com o mundo em que o aluno vive. Ao agir assim, o professor exalta e toma como modelo e código o mito positivista do especialista:

Aquele que possui a chancela de produzir verdades centradas na forma do discurso científico, balizadas por investigações mais rigorosas de uma parte do todo, sendo necessário para tal, fragmentar o saber em compartimentos hierarquicamente bem ordenados; isto é, o discurso científico é competente, por ser respaldado institucionalmente, portanto, autorizado e cabendo à teoria o papel de ser hierarquicamente superior à prática, por advir do campo das ideias (CHAVES, 2004, p.100). 
No ETM é de praxe que os saberes cotidianos sejam negligenciados em detrimento aos saberes escolares, chancelados academia, bem como por outras instituições de sequestro - no sentido foucaultiano. E ainda,

[...] o conteúdo programático é o elemento central, principal e irrefutavelmente é colocado além do bem e do mal. A aula expositiva, nos moldes do ETM, é o lugarcomum da pregação enunciativa do expositivista ou de práticas educativas expositivistas; uma aula onde o professor - ser falante - ocupa grande parte do tempo envolvido com a exposição, e, o aluno - ser ouvinte - aceita passivamente as verdades apresentadas (CHAVES, 2004, p.79).

O ambiente de aprendizagem peculiar às práticas educativas expositivistas, pautadas pelo monólogo do professor - o ser falante (pergunta e responde a ele mesmo) - é "apresentado através do discurso unilateral, do professor, com referências à Matemática e onde uma programação curricular rígida se põe à frente do processo". (CHAVES, 2004, p.79). Nessa obra é possível observar que no ETM os métodos de ensino hegemônicos não utilizam práticas voltadas à realidade, nem como ponto de chegada, nem como ponto de partida; muito menos como táticas, seja à fixação ou à construção da aprendizagem, isso porque nas instituições escolares - instituições de sequestro, no sentido foucaultiano, para Chaves (2004) atividades de tal envergadura são tidas como possíveis instrumentos de ruptura no exercício de controle e do "expositivismo professoral"8. Já educadores, quando as utilizam, o fazem tão-somente de maneira ilustrativa ou lúdica, como passatempo e não como procedimento de ensino ou uma possível tática de transformação da

\footnotetext{
8 Termo cunhado por Chaves (2004, p.87) para designar um ambiente favorável à perpetuação do efeito Dolly ou clonagem acadêmica (perpetuação dos iguais) que é um instrumento tático que colabora para "a manutenção do ETM e, por conseguinte, com as formas de poder que se perpetuam na e a partir da escola".
} 


\section{DEEDebates \\ em Educação Científica e Tecnológica \\ ISSN - 2236-2150 (Eletrônica)}

realidade a partir da aprendizagem. A prova cabal de tal afirmação pode ser vista nas Diretrizes Curriculares Nacionais - DCN - (BRASIL, 2013):

A escola tem tido dificuldades para tornar os conteúdos escolares interessantes pelo seu significado intrínseco. É necessário que o currículo seja planejado e desenvolvido de modo que os alunos possam sentir prazer na leitura de um livro, na identificação do jogo de sombra e luz de uma pintura, na beleza da paisagem, na preparação de um trabalho sobre a descoberta da luz elétrica, na pesquisa sobre os vestígios dos homens primitivos na América e de sentirem o estranhamento ante as expressões de injustiça social e de agressão ao meio ambiente (BRASIL, 2013, p. 116).

Em outra trajetória, provavelmente devido à ausência de material que busque uma possível confluência, pode se pensar que as preocupações pertinentes à tríade, Modelo dos Campos Semânticos (MCS), Teoria da Atividade e proposta de uma Educação etnomatemática, seja antagônica ou não compartilha um mesmo espaço comunicativo; todavia, fruto de nossas pesquisas e trabalhos, verificamos que há pertinência e que é possível efetuarmos propostas de intervenção em práticas educativas, tomando como lastro tal referencial; isto é, não há uma relação tricotômica entre esses três sustentáculos teóricos, mas sim uma tríade formada pelos mesmos que possibilita que coloquemos em prática uma educação pautada nas premissas apresentadas $\left(\left(\mathrm{P}_{1}\right)\right.$ a $\left.\left(\mathrm{P}_{8}\right)\right)$.

O que nos propusemos a estudar, em nossa pesquisa de pós-doutorado, verificar e analisar se existe $(m)$ possibilidade(s) de efetuar relação(ões) entre o MCS, a Teoria da Atividade e uma possível proposta de uma educação etnomatemática, com vistas a quebrar a inércia mantenedora do ETM. Para tal, neste texto, entendemos saberes cotidianos como modos não hegemônicos de matematizar, bem como dinâmicas matemáticas não legitimadas pela academia e saberes 
escolares como modos hegemônicos de matematizar, bem como dinâmicas matemáticas legitimadas pela academia.

É usual que a Matemática como área de conhecimento, no contexto escolar, sobretudo na Educação Básica, mantenha um caráter meramente teórico. Em nossa prática docente, como formadores e acadêmicos, observamos que alunos e professores clamam por utilizarem a Matemática de forma prática, palpável, como "ferramenta de leitura do mundo" (CHAVES, 2004), para que possam, por exemplo, se apropriar da mesma em projetos pedagógicos, fato que dificilmente ocorre e, quando ocorre, restringe-se a leituras que redundam em análise superficiais e de baixíssima densidade epistêmica de gráficos de setor circular ou gráficos de barras. Tal cenário assim se configura principalmente porque em seu processo de formação, o professor tem acesso exclusivo a uma Matemática puramente teórica, onde se estuda a Matemática pela, por e para a Matemática em detrimento de possíveis aplicações.

Entendemos que, ao buscarmos alicerçar a tríade MCS, Teoria da Atividade e uma possível proposta de uma Educação etnomatemática, a partir de nossas premissas, não apenas opomo-nos ao que fora exposto no parágrafo antecedente, mas também desestabilizamos a inércia mantenedora do ETM, logo combatemos o fracasso do ensino Matemática e suas táticas positivistas e meritocráticas.

\subsection{As Premissas que Balizaram a Construção do Texto, da Pesquisa e das Práticas}

O desenvolvimento do nosso trabalho, tanto no campo da ação - no desenvolvimento das práticas - quanto no campo da redação deste texto, foi pautado por princípios que, para nós, são balizares e, portanto, tomados como premissas de base histórica, cultural e ideológica. Tais princípios, apresentamos a seguir formando as oito premissas $\left(\left(P_{1}\right)\right.$ a $\left.\left(P_{8}\right)\right)$ que alicerçam também nossas práticas. 
$\left(P_{1}\right)$ - No que se refere aos processos de formação de professores (inicial e continuada) é indispensável que se trabalhe indissociavelmente a partir da tríade ensino, pesquisa e extensão para nos contrapormos ao ETM.

$\left(P_{2}\right)$ - Que se tome como referência e modelo as concepções de Patrick Geddes (conforme (cf.) nota de rodapé (NRP) 10).

$\left(P_{3}\right)$ - Frente a diferentes realidades, distintos saberes (inclusive de natureza matemática) são produzidos.

$\left(\mathrm{P}_{4}\right)$ - A intervenção sociocultural de uma ação pedagógica não vinculada à realidade dos alunos possibilita um enfraquecimento da identidade cultural desses alunos e a torna frágil (a identidade) no que se refere à manutenção de seus valores.

$\left(P_{5}\right)$ - Quem produz significado não é o emissor, mas o receptor da enunciação, portanto, a produção de significado se dá sempre no interior de atividades (LINS, 1999, p.88).

$\left(P_{6}\right)$ - As formas como se produz conhecimento são dependentes de diversas variáveis que compõem as dinâmicas de uma cultura, logo, não há como pensar em produção única que seja válida em todos os contextos a todos os indivíduos.

$\left(P_{7}\right)$ - A Educação Matemática que defendemos produz legitimidade, dentro da escola, para os modos de produção de significado da rua (ato político, ato pedagógico) (LINS, 1999, p.92).

$\left(P_{8}\right)$ - O desenvolvimento intelectual se origina na interiorização de formas produzidas socialmente (VYGOTSKY apud LINS, 1999, p.79). (CHAVES, 2015, p.7-8). 


\section{LASTRO EPITEMOLÓgICO E Algumas Noções-CATEGORIAS do MCS}

\subsection{UM ENTENDIMENTO DE ATIVIDADE}

O conceito de atividade adotado por nós é o mesmo do MCS, empregado por Leontiev em sua Teoria da Atividade, voltada a um domínio coletivo, desenvolvida, a partir dos postulados básicos de $V_{y g o t s k y}{ }^{9}$ - onde se entende que todo conhecimento $^{10}$ é produto social e, portanto, resultado das interações humanas. Logo, entendemos que atividade é processo e atividade humana é forma de relação do homem com o mundo, construída historicamente, mediada por instrumentos, dirigida por motivos, fins a serem alcançados, é orientada por objetivos, visto que o homem age intencionalmente, a partir de ações planejadas.

Para explicar a diferença entre os níveis de funcionamento da atividade humana - operação, ação e atividade propriamente dita - Leontiev (OLIVEIRA, 1997) utiliza a metáfora da caça, onde há tarefas distintas desenvolvidas, como, por exemplo, afugentar a caça (direcionando-a para uma armadilha) para ser alvejada, depois de alvejada a caça é carneada, separando-se a carne (que serve para alimentação) do couro (que serve para indumentária). Caçar é a atividade propriamente dita. Afugentar, alvejar, carnear, armazenar a carne, preparar os alimentos, preparar o couro para indumentária etc. são as ações. As formas de

\footnotetext{
${ }^{9}$ Lev Semionovich Vygotsky (1896-1934), pioneiro na fundamentação de que o desenvolvimento intelectual das crianças ocorre em função das interações sociais e condições de vida. Argumentava que o desenvolvimento mental da criança é um processo contínuo de aquisição de controle ativo sobre funções inicialmente passivas enquanto que o desenvolvimento intelectual e linguístico, da criança, está relacionado à interiorização do diálogo em fala interior e pensamento.

${ }^{10}$ No MCS conhecimento é uma crença-afirmação associada a uma justificação que nos permite produzir aquela enunciação. Ele é do domínio da enunciação e há sempre um sujeito do conhecimento (cognitivo e não biológico), que não é do conhecer. (LINS, 2012, 1999). Pelo mesmo referencial entendemos "enunciação como o ato de enunciar algo a algum interlocutor e, discurso, como uma enunciação ou um enunciado (resíduos de uma enunciação). Ambos utilizam, constantemente, um processo de inferência lógica dedutiva por meio da linguagem." (SAD, 1999, p.123 grifos do autor).
} 


\section{DE Debates \\ ISSN - 2236-2150 (Eletrônica)}

afugentá-la podem ser por meio de fogo, barulho com tambores, cornetas, gritos etc. Da mesma maneira que as formas de alvejar podem ser com arco e flecha, lança, tiro etc. O preparo do alimento pode ser feito através de cozimento, fritura, assado etc. Essas formas de desempenhar as ações denominam-se operações.

Figura 1: Níveis de funcionamento da atividade humana segundo Leontiev. Fonte: Loures \&

Pinto (2015)

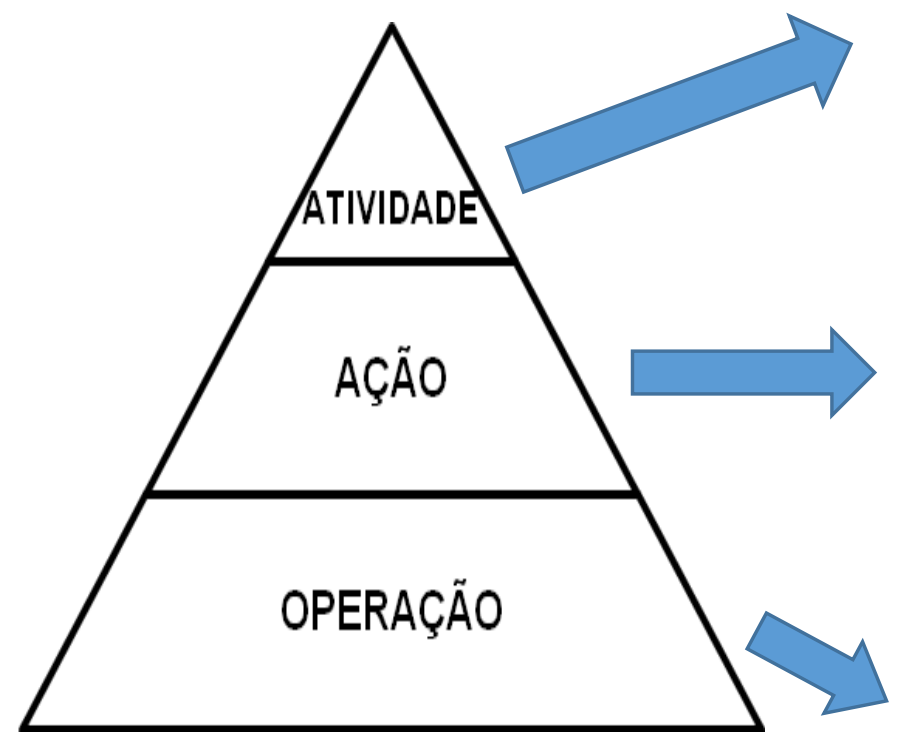

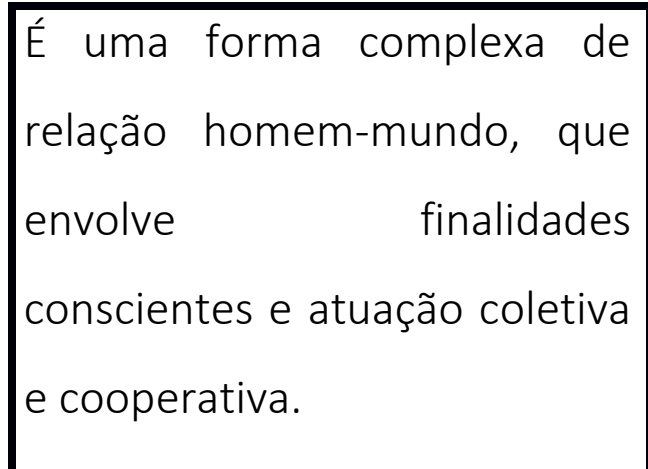

É o processo em que o objeto

e o motivo não coincidem, mas esta ação faz parte da atividade. Ela é ao mesmo tempo estimulada pelo motivo e direcionada para o objetivo. "Visivelmente a ação só é possível no seio de um processo coletivo agindo sobre a natureza.". (LEONTIEV, 1984, p.69). 


Constitui-se como o terceiro
nível da atividade humana,
que se refere aos modos de
execução de uma tarefa e se
configura como aspecto
operacional de uma ação.
(SILVA. 2003, p.33).

Leontiev (1978) defende a necessidade do sujeito como preponderante para estabelecer condição à existência da atividade e esta é determinada tão-somente pela existência de um objeto ${ }^{11}$ que a estimula, que é o motivo de sua ocorrência. Logo, para que a atividade exista é primordial que o objeto da ação coincida com o motivo.

O princípio gerador ao desenvolvimento de uma atividade é uma necessidade e, enquanto processo, uma atividade inclui manifestações externas - que são observáveis - e também manifestações internas e componentes mentais. As manifestações externas se processam a partir de níveis de funcionamento, que são as ações e as operações, cuja significação social é produzida a partir de elementos coletivos, como vimos no caso da metáfora da caça, por exemplo.

\subsection{O Modelo dos Campos Semânticos (MCS) e Possíveis Interações com uma Proposta de} UMA EdUCAÇÃo ETNOMATEMÁTICA

O MCS foi desenvolvido por Romulo Campos Lins, a partir de 1986, e apresentado em 1992 na tese de doutorado, de sua autoria, intitulada "A framework for understanding what algebric thinking is" (Um quadro de referência para entender

\footnotetext{
11 Objeto é aquilo para que se produza significado (LINS, 2012, p.28), ou “'algo' do qual o sujeito pode falar a respeito" (SAD, 1999, p.126 - grifos do autor).
} 


\section{E Eebates \\ em Educação Científica e Tecnológica \\ ISSN - 2236-2150 (Eletrônica)}

o que é pensamento algébrico), defendida na University of Nottingham (UK), vislumbrando a possibilidade de ir além da relação dicotômica de "acertar" ou "errar", pois seu propósito está vinculado a inquietações pertinentes a professores; sobretudo, os de Educação Básica, que tentam caracterizar e compreender aquilo que leva os alunos a "errarem", mas sem colocar o "erro" como um elemento para fins meritocráticos. Ao desenvolver o MCS, Romulo Campos Lins objetiva "dar conta de caracterizar o que os alunos estavam pensando quando 'erravam', mas sem recorrer a esta ideia de erro" (LINS, 2012, p.11), para que os mesmos passassem a questionar suas próprias respostas, produzindo significados.

Todavia, nossas inquietações a respeito do tema em questão encontraram sua gênese em um texto deste autor (LINS, 1993) quando examinávamos os fundantes do MCS na tentativa de relacionar tal modelo com nossa prática. Na obra em curso encontramos os primeiros rudimentos que acenam à possibilidade de se trabalhar em uma interface entre o MCS, a Teoria da Atividade e a uma possível proposta de uma Educação etnomatemática com o propósito de atacar uma possível tricotomia entre elas.

A partir do MCS, entendemos a produção de significado como "o aspecto central de toda aprendizagem - em verdade o aspecto central de toda a cognição humana." (LINS, 1999, p.86), onde o significado é o conjunto de coisas que se diz a respeito de um objeto. Não o conjunto do que se poderia dizer, e, sim, o que efetivamente se diz no interior de uma atividade. Produzir significado é, então, falar a respeito de um objeto (LINS; GIMENEZ, 1997, p.145-146).

Dessa forma, as atividades que propusemos e desenvolvemos junto ao(à)s atores(atrizes) do processo voltaram-se à aprendizagem e, por conseguinte, à produção de significado. 
Também a partir do MCS, entendemos que nós - professora(e)spesquisadora(e)s - enquanto leitores ${ }^{12}$, buscamos a partir da análise da produção de significado, efetuar uma leitura plausível, que é toda tentativa de se entender um autor $^{13}$, passando pelo esforço de olhar o mundo com os olhos do autor, usando os termos que ele usa de forma que o todo do seu texto ${ }^{14}$ (do que fala) torne-se plausível. (LINS, 1999, p.93).

Assim, autor/leitor/texto são os elementos constitutivos de um processo comunicativo, onde o autor (emissor da enunciação) não é quem produz significado, pois este é produzido pelo receptor (leitor) da enunciação (texto ${ }^{15}$, tal como apresentado em $\left(P_{5}\right)$. Ao realizar uma leitura plausível consideramos a aproximação de "um olhar antropológico que procura conhecer como a cultura de um determinado grupo social funciona, sem a necessidade de alteração ou mudança desse ambiente por julgá-lo menos ou mais importante pelos olhos de quem o estuda". (FRANCISCO, 2008). Esse entendimento é consonante com o que apresentamos nas premissas $\left(P_{2}\right),\left(P_{4}\right)$ e $\left(P_{7}\right)$.

Com base no que expusemos, torna-se relevante destacar que, o MCS admite a perspectiva de que o conhecimento produzido pelo aluno pode não ser o mesmo produzido e enunciado pelo professor; todavia, ambos são considerados válidos e, dessa forma, para nós, conhecimento "é entendido como uma crença - algo que o sujeito acredita e expressa, e que se caracteriza, portanto, como uma afirmação -

\footnotetext{
12 O leitor é quem ouve - o receptor da enunciação - é aquele que, no processo, se propõe a produzir significados para o resíduo das enunciações.

${ }^{13}$ Autor é quem fala - o emissor de uma enunciação - aquele que no processo produz a enunciação.

${ }^{14}$ Texto é qualquer resíduo de enunciação para o qual o leitor produza algum significado.

15 Lins (1999, p.87) chama atenção ao fato de que toda produção de significado implica produção de conhecimento e que quem produz significado não é o emissor, mas o receptor de uma enunciação.
} 
junto com o que o sujeito considera ser uma justificação para sua crença-afirmação" (LINS, 1993, p.88) e, por ser do domínio da enunciação, só existe em sua enunciação, sendo aquilo que alguém diz sobre algo e dar legitimidade a uma enunciação é um dos papéis da justificação que é parte do que constitui um conhecimento (LINS, 1999).

Para Cezar \& Chaves (2016, p.4-5), em um processo de produção de significado é estabelecido um espaço comunicativo ${ }^{16}$ tomado como processo de interação onde os interlocutores ${ }^{17}$ são compartilhados e a enunciação é produzida pelo autor que fala na direção de "um" leitor, constituído pelo autor. Por sua vez, esse "um" leitor produz significado à enunciação e fala na direção de "um" autor, constituído pelo leitor. "De acordo com esta perspectiva, durante todo o processo de comunicação são relacionados três elementos fundamentais: autor, texto e leitor." (CEZAR; CHAVES, 2016, p.4-grifos dos autores).

Considerando as premissas $\left(P_{3}\right)$ e de $\left(P_{5}\right)$ a $\left(P_{8}\right)$ é possível observar que as mesmas vão em direção do que é apresentado pelos PCN:

A atividade matemática escolar não é "olhar para as coisas prontas e definitivas", mas a construção e a apropriação de conhecimento pelo aluno, que se servirá dele para compreender e transformar sua realidade;

No ensino da Matemática, destacam-se dois aspectos básicos: um consiste em relacionar observações do mundo real com representações (esquemas, tabelas,

\footnotetext{
${ }^{16}$ Um espaço comunicativo não é algo físico, mas do campo da cognição, visto que este é constituído pelo compartilhamento de interlocutores, pois "toda produção de conhecimento é feita na direção de um interlocutor que, acredito, produziria a mesma enunciação com a mesma justificação." (LINS, 1999, p.88 - grifos do autor).

17 “Qualquer agente que propicie o desenvolvimento psicológico do sujeito, não necessariamente uma pessoa. (O termo psicológico, de acordo com Vygotsky, inclui tanto o cognitivo quanto o afetivo)." (SAD, 1999, p.124 - grifos do autor).
} 


\section{E Eebates \\ em Educação Científica e Tecnológica \\ ISSN - 2236-2150 (Eletrônica)}

figuras, escritas numéricas); outro consiste em relacionar estas representações com princípios e conceitos matemáticos. Nesse processo, a comunicação tem grande importância e deve ser estimulada, levando-se o aluno a 'falar' e a 'escrever' sobre Matemática, a trabalhar com representações gráficas, desenhos, construções, a aprender como organizar e tratar dados;

O significado da Matemática para o aluno resulta das conexões que ele estabelece entre ela e as demais áreas, entre ela e os Temas Transversais, entre ela e o cotidiano e das conexões que ele estabelece entre os diferentes temas matemáticos;

A seleção e organização de conteúdos deve levar em conta sua relevância social e sua contribuição para o desenvolvimento intelectual do aluno e não deve ter como critério apenas a lógica interna da Matemática. (BRASIL - 1998, p.56-57 - grifo nosso).

Grifamos a citação antecedente para destacarmos a convergência com nossas premissas, sobretudo, $\left(P_{2}\right),\left(P_{4}\right),\left(P_{6}\right),\left(P_{7}\right)$ e $\left(P_{8}\right)$ e com nosso lastro teórico, principalmente no que se refere à ideia de uma possível Educação etnomatemática, à Educação Matemática que praticamos, a partir do MCS e o papel de saberes e conhecimento não hegemônico discutido a partir de Knijnik et al (2012) .

Dessa forma é legítimo que busquemos meios que se contrapunham ao ETM para combater as disparidades e distorções, apontadas pelos PCN (BRASIL, 1998). A partir do conjunto de premissas supracitado e das considerações apresentadas a partir de Brasil (1998), é possível discutir não apenas a política de conhecimento dominante praticada na escola, mas também trazer à tona o conhecimento não hegemônico produzido por aqueles que não são chancelados pela academia (e órgãos governamentais) - saberes populares - advindos de práticas sociais e 


\section{DEDebates \\ em Educação Científica e Tecnológica \\ ISSN - 2236-2150 (Eletrônica)}

confrontá-los com a política de conhecimento dominante. Para tal tomamos a Teoria da Atividade, o MCS e também a Etnomatemática. Por hora, vale salientar que:

O pensamento etnomatemático está centralmente interessado em examinar as práticas de fora da escola, associadas a racionalidades que não são idênticas à racionalidade que impera na Matemática Escolar, com seus estreitos vínculos com a razão universal instaurada pelo lluminismo. Mas é preciso que se diga: olhar para essas outras racionalidades, sem jamais se esquecer do que está no horizonte, é pensar outras possibilidades para a Educação Matemática praticada na escola. (KNIJNIK et al, 2012, p.18)

Assim, Knijnik et al (2012) possibilita que emerja a heterogeneidade de se matematizar a partir de procedimentos não referendados pela academia - os não hegemônicos - e discutir quais motivos que impossibilitam que os mesmos sejam tomados como modelo e código. Mais do que indagar "quem", preocupamo-nos com "o que" é delimitado como "verdadeiro" ou "falso" nas diferentes áreas do conhecimento e quem passa a deter a posição de enunciador dessas "verdades". Pensando essas questões para a área de Educação Matemática, podemos nos perguntar: quais saberes contam como "verdadeiros" nas aulas de Matemática? Quais são desqualificados como saberes matemáticos no currículo escolar? Quem tem a legitimidade para definir isso? (KNIJNIK et al, 2012, p.16)

Aí temos um elemento aproximativo do MCS à Etnomatemática, pelo menos a que propomos, que se dá a partir do entendimento de Lins $(1999$, p.92) a respeito de uma Educação Matemática praticável:

1. explicitar, na escola, os modos de produção de significado da rua;

2. produzir legitimidade, dentro da escola, para os modos de produção de significado da rua (ato político, ato pedagógico) $\left(\mathrm{P}_{7}\right)$; 


\section{DE Eebates \\ em Educação Científica e Tecnológica \\ ISSN - 2236-2150 (Eletrônica)}

3. propor novos modos de produção de significado, que se juntam aos da rua, ao invés de substituí-los (LINS, 1999, p.92).

O que é realmente relevante é que tradicionalmente a escola negou os significados da rua, e se esforçou em tentar implementar o domínio dos significados da escola; no caso da Matemática, os significados matemáticos (oficiais), e aqui voltamos outra vez a importância de examinarmos pressupostos (LINS, 1999, p.90).

Por esse prisma o trânsito entre esses saberes (escolares e socialmente constituídos) possibilita que busquemos interlocuções e ajustes na efetiva comunicação na relação autor/texto/leitor produzidas com o propósito de se constituir um espaço comunicativo. Dessa maneira, ancorados pelos que apresentamos a respeito de atividade, interdisciplinaridade, Etnomatemática e MCS, entendemos, ser possível então, tomar a Matemática como um sistema cultural:

Trata-se de pensá-la não de forma abstrata, imune às lutas do campo simbólico que buscam a manutenção ou ascensão nas posições do espaço social onde ela é produzida e reproduzida. Ao contrário, busco entende-la, enquanto uma das manifestações simbólicas de um determinado grupo social, relacionada com sua posição de dominação ou subordinação no espaço social onde está inserido. Mais ainda, considero que não só a Matemática é uma manifestação simbólica: falar a seu respeito, teorizar sobre ela, interpretá-la, também o é. (KNIJNIK, 1996, p.95-96).

Mais do que possível é legítimo. Não por uma questão de autoridade, pois como aponta Lins $(2012$, p.21) "a autoridade não 'explica' nada, ela apenas autoriza, empresta legitimidade" (grifos do autor), visto que,

O que se internaliza não é o conteúdo, não são conceitos, e sim legitimidades: a pessoa já era capaz de fazer; mas não sabia que nesta ou naquela situação aquilo era legítimo, que nesta ou naquela situação aquele modo de produção de significado era legítimo. [...] internalizar interlocutores, legitimidades, é o que 
torna possível a produção de conhecimento e significado, torna possível antecipar uma legitimidade do que digo. (LINS, 2012, p.20).

Assim, entendemos que é possível, e ao mesmo tempo fundamental, firmarmos compromisso com respeito às diversidades (socioambiental e cultural), compartilhando - nas atividades desenvolvidas com o(a)s aluno(a)s, na organização e sistematização das ações do grupo (daqueles que se configuram como atores/atrizes deste texto) - os modos próprios "de saber, de fazer e de conviver de cada cultura, para sua sobrevivência e transcendência." (SCANDIUIZZI; LÜBECK, 2011, p.144).

Pelo prisma da Etnomatemática é possível discutir não apenas a política de conhecimento dominante praticada na escola, bem como fazer emergir conhecimento não hegemônico - produzido por aquele que não é chancelado pela academia (saberes populares) - advindo de práticas sociais e confrontá-lo com a política de conhecimento dominante, portanto, hegemônico e chancelado (saberes oficiais ou dominantes). Nessa direção é possível observar que as DCN apontam que

[...] o conhecimento de valores, crenças, modos de vida de grupos sobre os quais os currículos se calaram durante uma centena de anos sob o manto da igualdade formal, propicia desenvolver empatia e respeito pelo outro, pelo que é diferente de nós, pelos alunos na sua diversidade étnica, regional, social, individual e grupal, e leva a conhecer as razões dos conflitos que se escondem por trás dos preconceitos e discriminações que alimentam as desigualdades sociais, étnicoraciais, de gênero e diversidade sexual, das pessoas com deficiência e outras, assim como os processos de dominação que têm, historicamente, reservado a poucos o direto de aprender, que é de todos. (BRASIL, 2013, p.115)

Quando nos referimos a uma Educação etnomatemáica, pensamos em uma educação para o ambiente onde tentamos "harmonizar sensações, sentimentos, razão e intuição na prática educativa, numa espécie de ecologia do 


\section{DE Debates \\ em Educação Científica e Tecnológica \\ ISSN - 2236-2150 (Eletrônica)}

ser/saber/fazer/conviver das diversidades culturais". De interação e dinamização, usufruindo os saberes das várias áreas do conhecimento, com interesses pedagógicos, científicos, socioambientais, culturais e humanos para com os seus envolvidos. Entendemos ecologia como "o estudo da estrutura e do desenvolvimento das comunidades humanas em suas relações com o meio ambiente (natureza) e sua consequente adaptação a ele, explicando a dinâmica dos sistemas sociais que afetam e são afetados por todos os aspectos da cultura." (SCANDIUZZI; LÜBECK, 2011, p.133). Esse entendimento coaduna com o exposto pelas DCN (BRASIL, 2013, p.115) e sustenta-se pelas premissas $\left(P_{2}\right),\left(P_{4}\right),\left(P_{6}\right),\left(P_{7}\right)$ e $\left(P_{8}\right)$.

\section{MetOdOLOGIA}

No que tange à apresentação da redação deste texto, segundo Gil (2010), deparamo-nos com uma pesquisa de abordagem qualitativa, cujo método empregado foi bibliográfico no âmbito teórico; todavia, caracterizamos uma vertente que, na perspectiva da prática, deu-se a partir da pesquisa-ação, no âmbito da proposta de ação diferencial, propiciando a interlocução com o(a)s atores(atrizes) do processo, na busca de um levantamento coletivo relativo às questões que os mesmos trazem, principalmente em relação à educação escolar a ser desenvolvida junto aos seus grupos culturais. Para tal tomamos como suporte Baldino \& Carrera de Souza (1997), Brasil (2013 e 1998), Chaves (2015, 2005, 2004 e 2000), Francisco (2015), Garnica (2010), Knijnik et al (2012), Knijnik (1996), Lins (2012, 1999, 1997 e 1993), Martins-Salandim (2012), Novais (2017), Sad (1999), Reisdoerfer (2015) Silva \& Lins (2013) e Silva (2003), com vistas a alicerçar possíveis diálogos entre práticas hegemônicas e não-hegemônicas de Matemática, a Etnomatemática, a Teoria da Atividade e o MCS.

Para implementar táticas (sistemática do conjunto de ações desenvolvidas pelo professor (CHAVES, 2000, p.201) que permitam atingir as premissas (de $\left(\mathrm{P}_{1}\right)$ a 


\section{DE Eebates \\ em Educação Científica e Tecnológica \\ ISSN - 2236-2150 (Eletrônica)}

$\left(\mathrm{P}_{8}\right)$ ) envolvemo-nos com dois programas desenvolvidos na UFSM: (i) o Programa Institucional de Bolsa de Iniciação à Docência (Pibid), a partir do Projeto Pibid Interdisciplinar do Campo, coordenado pela Profa Dra Ane Carine Meurer, do CE da UFSM, que objetiva trabalhar com o Ensino Fundamental nas escolas do campo, a partir da inserção e interação das várias licenciaturas da UFSM;

As escolas do campo dificilmente têm sido procuradas para estágios das licenciaturas, no entanto, são espaço-tempo que merecem ser pesquisadas e compreendidas na sua singularidade, na sua riqueza cultural, econômica e política. As escolas do campo ao serem pesquisadas e trabalhadas pelas licenciaturas da UFSM podem ser compreendidas na diversidade que as constitui, a partir do reconhecimento das suas peculiaridades (MEURER, Ane Carine, 2013, p.1-2).

(ii) O Programa de Educação Tutorial, PET Matemática, coordenado pela Profa Drạ Carmem Vieira Mathias, do DEMAT. Pelo Pibid, formamos parceria com a licencianda Patrícia e com a Professora Vera e pelo PET Matemática formamos parceria coma licencianda Maísa.

Formado o grupo de professora(e)s-pesquisadora(e)s propusemo-nos a confrontar os dispositivos de controle do ETM com ações planejadas que visam alcançar objetivos estabelecidos pelo grupo para produção de materiais didáticopedagógicos (MDP) e práticas pautadas por atividades propriamente dita, ações e operações que permitissem que os envolvidos no processos (aluna(o)s e professora(e)s) pudessem refletir a respeito de sua prática no que tange o tema proposto, de modo que os mesmos pudessem intervir em sua própria sala de aula, a partir de sua margem natural de liberdade.

Para analisarmos a produção de significados dos alunos a partir dos resíduos de enunciação, acerca da caracterização do pensamento espacial em relação às técnicas e práticas adotadas em nossas propostas de ações e operações relativas às 


\section{E Eebates \\ em Educação Científica e Tecnológica \\ ISSN - 2236-2150 (Eletrônica)}

atividades desenvolvidas, pautamo-nos em suas narrativas apresentadas, tanto no decorrer de cada uma das ações, quanto no momento das plenárias, ao término de cada atividade. Usamos um procedimento peculiar da História Oral de transcrição de depoimentos e em seguia adotamos a análise de convergências e de singularidades.

A respeito da transcrição do depoimento, ou seja, a passagem para o escrito de todos os diálogos entre depoentes e entrevistador, Garnica (2010) esclarece que, o motivo da passagem do relato oral para o escrito deve-se à facilidade de manuseio e durabilidade que a escrita oferece, favorecendo uma pluralidade de leitores. No texto em questão, o autor aponta que:

as histórias que os sujeitos nos contam, suas descrições, suas narrativas, servem para constituir outras narrativas nas quais a voz do pesquisador está irremediavelmente contaminada pelas vozes daqueles que teve como interlocutores. (GARNICA, 2010, p.6).

Tal observação coaduna com ideias valiosas ao MCS, quando referimo-nos à $\left(P_{5}\right)$ e à necessidade de estabelecermos um espaço comunicativo com o propósito de efetuarmos leituras plausíveis com vistas à produção de conhecimento.

Quanto à utilização do procedimento de análise de convergências e similaridades fomos a, Martins-Salandim (2012), Reisdoerfer (2015) e Novais (2017) que, além de fontes escritas-documentos e registros cartográficos, tais textos utilizaram narrativas dos atores de suas respectivas pesquisas, onde, a partir de uma primeira leitura, do conjunto de depoimentos, narrativas e resíduos de enunciações, elaboraram categorias de análise (temas comuns trazidos pelos depoentes) que ajudaram a compor um panorama mais geral sobre os respectivos objetivos de suas pesquisas. 


\section{DE Eebates \\ em Educação Científica e Tecnológica \\ ISSN - 2236-2150 (Eletrônica)}

Salientamos que as narrativas, entrevistas e relatos também foram utilizados por nós como instrumento de investigação, observando singularidades e convergência a partir dessas enunciações. Para tal, adotamos como metodologia para analisar as narrativas dos atores projetos historiográficos - como o nosso quando desenvolvidos segundo as tramas da História Oral, permitem ao mesmo tempo o deslanchar de dois projetos num mesmo projeto, numa mesma operação historiográfica: uma mais memorialística, voltada às singularidades das vidas e experiências relatadas (que tentamos captar a partir do que denominamos "análise de singularidades") e outra, mais propriamente historiográfica (captada no que denominamos "análise de convergências") (MARTINS-SALANDIM, 2012, p. 61).

Assim, a tipologia de análise (convergências e similaridades) permitiu que elaborássemos um espectro mais amplo a respeito do tema pesquisado, da mesma forma adotada por Silva \& Lins (2013), que denominou de leitura global. A leitura global, por si só não permite que façamos uma análise refinada na dinâmica de produção de significado dos atores. Já a análise de singularidades, que se aproxima do que Silva \& Lins (2013) denominaram de leitura local, busca olhar para cada narrativa produzida, registrando o que cada colaborador revela e faz refletir a respeito do objetivo do trabalho. Este tipo de análise possibilitou um olhar mais denso a respeito das singularidades de cada ator(atriz). Dessa maneira, foi possível dialogarmos sobre questões mais pontuais, que ficariam perdidas em uma análise por convergências, mas dificulta um olhar geral sobre o tema estudado.

Ao todo, no intervalo de tempo de maio a novembro de 2016, desenvolvemos sete ações pedagógicas, que foram planejadas, executadas e replanejadas pela(o)s autora(e)s deste texto; todavia, devido a delimitação de espaço, discutiremos à luz do aporte teórico, as ações 1 e 3 - somente as operações relativas à ação 1 - (cf. Quadro 01 a seguir) a seguir. 
Quadro 1: Detalhamento de ações e respectivas operações

\begin{tabular}{|c|c|}
\hline Ações & Operações \\
\hline $\begin{array}{l}\text { Ação } 1 \text { - Mapeando } \\
\text { o trajeto casa-escola }\end{array}$ & $\begin{array}{l}\text { (1.1) O(A)S ALUNO(A)S DESENHARAM OS } \\
\text { PROTÓTIPOS DE MAPAS QUE O(A)S LEVASSEM DE } \\
\text { SUAS RESPECTIVAS CASAS À ESCOLA; } \\
\text { (1.2) com a ajuda dos familiares estimaram as } \\
\text { respectivas distâncias de suas casas à escola; } \\
\text { (1.3) consultaram os familiares a respeito de que } \\
\text { unidades de medidas os seus ancestrais utilizavam } \\
\text { e pesquisaram na internet a respeito de tais } \\
\text { unidades de medida e suas respectivas relações } \\
\text { com o metro. }\end{array}$ \\
\hline $\begin{array}{l}\text { Ação } 2 \text { - Medindo a } \\
\text { gente e o espaço } \\
\text { escolar }\end{array}$ & $\begin{array}{l}\text { (2.1) Unidades de medidas lineares (unidades } \\
\text { históricas e do Sistema Imperial, unidades } \\
\text { adotadas por seus ancestrais); } \\
\text { (2.2) unidades de medidas lineares (Sistema } \\
\text { Interacional e relação com as unidades históricas e } \\
\text { do Sistema Imperial, unidades adotadas por seus } \\
\text { ancestrais); } \\
\text { (2.3) uso de instrumentos para medir (bússola, } \\
\text { régua graduada, manga de nível, paquímetro, } \\
\text { trena, fita métrica); } \\
\text { (2.4) uso de gráficos para construir a identidade da } \\
\text { turma; }\end{array}$ \\
\hline
\end{tabular}




\begin{tabular}{|c|c|}
\hline & $\begin{array}{l}\text { (2.5) medindo a quadra de esportes da escola com } \\
\text { uso de instrumentos (linhas, perímetros e áreas - } \\
\text { usando a trena e a bússola); } \\
\text { (2.6) unidades de medidas de área (padrões do } \\
\text { sistema métrico e unidades agrárias: braça } \\
\text { quadrada, acre, are, hectare). }\end{array}$ \\
\hline $\begin{array}{c}\text { Ação } 3 \\
\text { Caça ao tesouro }\end{array}$ & $\begin{array}{l}\text { (3.1) Formando figuras poligonais no papel com } \\
\text { régua e transferidor; } \\
\text { (3.2) Operando com números na representação } \\
\text { decimal na calculadora; } \\
\text { (3.3) Formando figuras poligonais na quadra com } \\
\text { trena e bússola; } \\
\text { (3.4) Caçando o tesouro; } \\
\text { (3.5) Separando e repartindo o tesouro do baú. }\end{array}$ \\
\hline $\begin{array}{l}\text { Ação } 4 \text { - } \\
\text { Esquete do Malba } \\
\text { Tahan }\end{array}$ & $\begin{array}{l}\text { (4.1) Encenação da peça "Apresentando Malba } \\
\text { Tahan a Júlio César de Mello e Souza"; } \\
\text { (4.2) Selecionando os contos dos livros para leitura } \\
\text { nas férias. }\end{array}$ \\
\hline $\begin{array}{l}\text { Ação } 5 \text { - } \\
\text { Dinâmica chumbo } \\
\text { versus algodão }\end{array}$ & $\begin{array}{l}\text { (5.1) Uso de balança para medir e comparar } \\
\text { massas; } \\
\text { (5.2) Experimento: comparando volumes iguais e } \\
\text { massas diferentes; } \\
\text { (5.3) Experimento: comparando massas iguais e }\end{array}$ \\
\hline
\end{tabular}




\begin{tabular}{|c|c|}
\hline & $\begin{array}{l}\text { volumes diferentes; } \\
\text { (5.4) Experimento: comparando alturas iguais e } \\
\text { volumes diferentes; } \\
\text { (5.5) Experimento: comparando volumes iguais e } \\
\text { alturas diferentes; } \\
\text { (5.6) cálculo do índice de massa corpórea (IMC). }\end{array}$ \\
\hline $\begin{array}{lll}\qquad \text { Ação } & 6 \text { - } \\
\text { Dinâmica } & \text { dos } \\
\text { quadrinhos } & \end{array}$ & $\begin{array}{l}\text { (6.1) Formação de grupos para debater as Tirinhas } \\
\text { contidas nos envelopes; } \\
\text { (6.2) identificar possíveis elementos matemáticos } \\
\text { a partir de suas leituras desses textos midiáticos; } \\
\text { (6.3) discutindo e transcrevendo os significados } \\
\text { subjetivos e objetivos das palavras contidas nas } \\
\text { Tirinhas; } \\
\text { (6.4) plenária: debate em grupo para efetuar } \\
\text { análise de possíveis significados produzidos; } \\
\text { (6.7) exposição de cada grupo dos significados que } \\
\text { produziram. }\end{array}$ \\
\hline $\begin{array}{lll}\text { Ação } & 7 & - \\
\text { Adaptações } & \text { de } \\
\text { textos e encenações }\end{array}$ & $\begin{array}{l}\text { (7.1) Leitura coletiva do conto O caso dos } 35 \\
\text { camelos de Malba Tahan; } \\
\text { (7.2) trabalhando o problema matemático contido } \\
\text { no conto; } \\
\text { (7.3) adaptação do texto à cultura gaudéria; } \\
\text { (7.4) leitura coletiva do conto adaptado - O }\end{array}$ \\
\hline
\end{tabular}




\begin{tabular}{|l|l|}
\hline gaudério bom de contas e o caso das 35 facas; \\
(7.5) readaptação coletiva do texto com busca de \\
expressões e vocabulário típicos (regional); \\
(7.6) ensaios, confecção de cenários e figurinos; \\
(7.7) leitura coletiva de O diabo bom dos números \\
de Hans Magnus Enzensberger; \\
(7.8) trabalhando o problema matemático contido \\
no conto; \\
(7.9) adaptação do texto à cultura gaudéria; \\
(7.10) leitura coletiva do conto adaptado - Uma \\
Peleia entre o gremista do pijama azul e o \\
colorado dos números; \\
(7.11) readaptação coletiva do texto com busca de \\
expressões e vocabulário típicos (regional); \\
(7.12) ensaios, confecção de cenários e figurinos.
\end{tabular} \mid

Enquanto grupo, nós [professora(e)s-pesquisadora(e)s - autora(e)s deste texto - e o(a)s atores(atrizes) do processo], ao aplicarmos a sistemática do conjunto de ações desenvolvidas a partir do ciclo de discussão em grupo (cf. NRP 5, 7, 8 e 10), balizados pelos postulados de Patrick Geddes (cf. NRP 10 e (P2)), propusemo-nos a discutir e refletir a respeito das questões que envolvem o reconhecimento e o respeito às diversidades socioambientais, históricas e culturais, tal como sugerido em Scandiuzzi \& Lübeck (2011), portanto, focados no ser, no saber, no fazer e no 
conviver; sobretudo, partindo princípio alteridade ${ }^{18}$ e respeito, às raízes socioambientais, antropológicas, históricas, filosóficas e educacionais do conhecimento da cultura local.

\section{AÇÕes e OperaÇões ao LONGO do PROCESSO - As PRÁticas e Alguns Resíduos DE ENUNCIAÇÃO DOS ATORES DURANTE O PROCESSO}

Como dito anteriormente, as atividades que desenvolvemos foram pautadas em um conjunto de premissas $\left[\left(P_{1}\right)\right.$ a $\left.\left(P_{8}\right)\right]$ e estão ancoradas na Teoria da atividade, no MCS e a partir de um foco interdisciplinar para uma proposta de educação etnomatemática.

O 4으 distrito de Santa Maria, conhecido como Arroio Grande, localizado a pouco mais de 6 quilômetros da Universidade Federal de Santa Maria, é uma região que, em sua origem, recebeu os primeiros imigrantes do sul do país. Inicialmente vieram alguns poucos alemães e em seguida os italianos que foram majoritários. Hoje a região se destacada pelas fortes tradições culturais - principalmente agrárias (técnicas de plantio, culinária, danças, artesanato etc.) - da colônia italiana, porém, com a crise econômica instaurada pela turbulência política que se agrava no país, sofre com o êxodo rural. Muitos colonos vendem suas propriedades para morarem na região urbana, principalmente no entorno do campus da UFSM, no bairro Camobi. Como consequência dessa situação a oferta de empregos reduziu

\footnotetext{
${ }^{18}$ Que expressa a qualidade ou estado do que é outro ou do que é diferente, do que é distinto. Como princípio fundamental da alteridade consideramos que o homem, na sua vertente social, tem uma relação de interação e dependência com o outro; por esse motivo, o eu (autor/leitor) na sua forma individual só existe a partir de um contato com o outro (leitor/autor). Em nosso entendimento a alteridade implica que um indivíduo seja capaz de se colocar no lugar do outro, em uma relação baseada no diálogo (estabelecendo um espaço comunicativo entre ambos) e valorizando as diferenças existentes.
} 


\section{E Eebates \\ em Educação Científica e Tecnológica \\ ISSN - 2236-2150 (Eletrônica)}

sistematicamente na região e, consequentemente, a evasão escolar passou a ser fator preocupante para o(a)s educadore(a)s.

Diante desse quadro, evidenciamos que nossas práticas não foram motivadas tão-somente à aprendizagem de um conteúdo programático ou à defesa de um procedimento de ensino, mas ao resgate à cultura, às tradições socioculturais, históricas, ao respeito à diversidade, aos indivíduos, ao meio ambiente e à identidade do(a)s atores(atrizes).

Não nos preocupamos em ensinar um conteúdo ou, devido ao caráter interdisciplinar, estabelecer vários olhares a partir de um tema ou projeto pedagógico. Preocupamo-nos em disponibilizar formas (da Matemática, Ciências, Língua Portuguesa, Geografia etc.) de incentivá-lo(a)s a gostarem dos (e refletirem sobre) seus valores, sua história, suas origens e sua região.

\subsection{Ação 1-Mapeando O Trajeto Casa-Escola}

Rodolfo e Maísa chegaram à escola no início de maio. Vieram por intermédio do Pibid. Lá estava a Professora Vera bem como a Licencianda Patrícia, participantes do Pibib Interdisciplinar do Campo. Com o ano letivo em curso, uma prática chamou atenção. Professora Vera e Patrícia, ao trabalharem as unidades de medidas lineares, no sistema métrico decimal, desenvolveram com os alunos uma ação (Mapeando o trajeto casa-escola) que foi o pontapé inicial para nossos trabalhos em parceria aqueles que aqui descrevemos, não todos, mas alguns, devido à limitação de espaço do texto em questão.

No planejamento dessa ação estava em curso o resgate às tradições linguísticas da família (que unidades seus antepassados utilizavam para descrever certa distância), a utilização do quilômetro como múltiplo de uma unidade de distância para medir percursos maiores, mas também o reconhecimento de pontos 


\section{E Eebates \\ em Educação Científica e Tecnológica \\ ISSN - 2236-2150 (Eletrônica)}

(de lazer, comerciais, culturais etc.) e monumentos locais como referência à trajetória percorrida, o uso de estimativas para percursos maiores, a ideia intuitiva de escala e semelhança etc. Também a questão do trabalho artístico estava em evidência, pois os mapas vieram desenhados e coloridos, como obras de arte - como pinturas em telas. Outro fator de intencionalidade foi trabalhar a localização espacial e geográfica. Algumas operações dessa ação foram:

4.1.1. O(A)S ALUNo(A)S DESENHARAM OS PROtótipos de MAPAS QUE o(A)S LEVASSEM DE SUAS

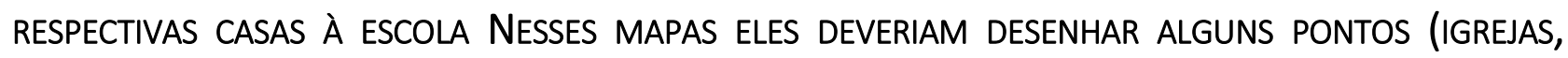
MONUMENTOS, ESTABELECIMENTOS COMERCIAIS ETC.) QUE ENTENDESSEM SER INTERESSANTES.

\subsubsection{COM A AJUDA DOS FAMILIARES ESTIMARAM AS RESPECTIVAS DISTÂNCIAS DE SUAS CASAS À ESCOLA.}

Com a intenção de construir a interatividade entre aluno e familiares, eles levaram para casa a pergunta: Qual a distância daqui de casa até a escola?

A fonte e a forma da consulta (que tipo de mídia seria usada) não foram estabelecidas, pois afinal a professora objetivava efetuar uma leitura plausível e também global no processo e em jogo estava a interação e as premissas $\left(P_{6}\right)$ e $\left(P_{7}\right)$. Ele(a)s apenas deveriam compartilhar o uso de estimativa com os familiares e relatar de que forma chegaram a tal mensuração.

Profe Vera - Como vocês, com a ajuda do pessoal de casa chegaram a essas estimativas?

Ator 6 - Eu e meu pai procuramos no Google Maps.

Ator 9 - Meu pai marcou no velocímetro da moto no dia em que me trouxe à escola.

Profe Vera - Boa ideia! Alguém mais marcou no carro a distância da casa até a escola? 


\section{DEDebates

Ator 1 - Eu pedi ao motorista do escolar, mas ele disse que o marcador estava quebrado.

Ator 2 - Meu pai fez as contas de cabeça. Ele é bom em calcular distância.

Profe Vera - Ah! Isso que teu pai fez chama-se estimar. Ele fez uma estimativa, uma aproximação.

Ator 6 - Mas o Google Maps é mais certo.

Profe Vera - Quando se faz uma estimativa, uma previsão, não precisa se chegar a um valor exato, basta que seja aproximado.

Ator 4 - Meu avô faz diferente. Ele costuma vim pra cá a pé e ele sabe que ele leva 1 hora andando lá de casa até aqui. Daí ele sabe que em 1 hora ele caminha mais ou menos $2 \mathrm{~km}$.

Nos resíduos de enunciação do Ator 6 é possível efetuarmos a seguinte leitura: a referência à mídia (ou texto) em questão é uma forma de dar credibilidade a sua resposta. O que nos leva a produzir tal conhecimento, tal crença-afirmação, justificase pela nossa observação e permanência em classe, no período de desenvolvimento de nosso trabalho. Neste intervalo de tempo identificamos que este ator apresenta uma preocupação exacerbada com os resultados, diríamos até que ele não se permitia errar - suas reações nos levam a tecer tal enunciação. Como o(a)s demais aluno(a)s não compartilham desse espaço comunicativo, não se estabelece entre ela - a classe - e o Ator 6 uma interlocução no que tange à questão, daí sua necessidade de buscar uma legitimação enunciando o quão preciso fora sua resposta devido ao recurso midiático adotado.

Observe que o Ator 4, em sua enunciação, subverte a ordem estabelecida, pois até então o tempo não havia sido mencionado, nem a velocidade de deslocamento. Com sua enunciação ele considera uma velocidade constante (a de caminhada de 
seu avô) e relaciona o tempo com a distância percorrida. Se observarmos (cf. NRP 22) o valor adotado pelo seu avô possui uma precisão conhecida e defendida pelos antigos, ou seja, a distância percorrida pelo Ator 4, segundo o conhecimento produzido por seu avô é de uma légua.

\subsubsection{CONSULTARAM OS FAMILIARES A RESPEITO DE QUE UNIDADES DE MEDIDAS OS SEUS ANCESTRAIS UTILIZAVAM E PESQUISARAM NA INTERNET A RESPEITO DE TAIS UNIDADES DE MEDIDA E SUAS RESPECTIVAS RELAÇÕES COM O METRO.}

Na primeira visita de Rodolfo e Maísa à classe do 5o ano o(a)s aluno(a)s, incentivados pela Profe Vera, apresentaram os trabalhos da ação Mapeando o trajeto casa-escola, expostos em um mural da sala de aula. Também expuseram quais dinâmicas utilizaram para realizar as respectivas estimativas dos percursos; alguns falaram da conversa com seus pais e avós que mediam tais distâncias em léguas ${ }^{19}$ e que pesquisaram na internet que uma légua linear equivale a 6.000 metros, mas que também acharam que em alguns lugares equivale a $7 \mathrm{~km}$ e em outros $2 \mathrm{~km}$.

A partir desta ação (Mapeando o trajeto casa-escola) e de suas falas, partimos para o planejamento de novas ações diferenciais (cf. NRP 7) e, para mantermos uma dinâmica de planejamento onde estivéssemos pautados pelas premissas $\left(\mathrm{P}_{1}\right)$ a $\left(\mathrm{P}_{8}\right)$ e na Teoria da Atividade, propusemo-nos a seguir a "sistemática do conjunto de ações desenvolvidas pelo professor no ciclo de discussão em grupo" (cf. NRP 8) e dando continuidade ao processo pusemos em curso a ação Medindo a gente e o espaço

\footnotetext{
${ }^{19}$ Légua era a denominação de várias unidades de medidas de itinerários, de longas distâncias percorridas, adotada em Portugal e, consequentemente, no Brasil, até a introdução do sistema métrico. Em algumas regiões do país, principalmente no interior, denomina “légua" à distância percorrida a pé (caminhada) por uma hora, aproximadamente 2 quilômetros, mas na maioria das vezes a légua terrestre é conhecida como 6 quilômetros.
} 


\section{E Eebates \\ em Educação Científica e Tecnológica \\ ISSN - 2236-2150 (Eletrônica)}

escolar. A imprecisão apresentada em relação à equivalência da légua serviu de mote para falarmos da necessidade de padronização a partir do Sistema Internacional de medidas e de introduzirmos com maior sistematização o sistema métrico.

Em uma análise de similaridades observamos que as famílias participaram do processo, chamando para si a responsabilidade de interação desse momento escolar. Em nenhuma das falas e dos resultados identificamos que não houve interação familiar, principalmente devido a prática social das famílias - tanto do campo quanto da área urbana - de se reunirem no final da tarde, antes do jantar, para uma rodada de chimarrão, lugar-comum onde se discute os ocorridos durante o dia.

Em uma análise de convergências observamos que, mesmo aqueles que se referiram a unidades de medidas não convencionais (léguas, jardas, pés etc.) tentavam relacioná-las com os múltiplos do metro, principalmente o quilômetro. Seus pais ainda referem-se a essa unidades utilizadas pelos seus antepassados, mas as unidades do Sistema métrico são referências nos seus labores.

\subsection{AÇÃo 3-CAÇA AO TESOURO}

Essa ação, mesmo possuindo um caráter lúdico e prático (no sentido da experimentação), com auxílio de instrumentos para determinar distância e direção, portanto, matematicamente com uma leitura de coordenadas polares a partir de trena (de 5m - para medir distância) e bússola (para medir direção), possibilitou que realizássemos algumas leituras interessantes, no que se refere a análise da produção de significado, para dar conta da caracterização do pensamento espacial apresentado pelo(a)s atore(atrize)s.

A classe foi dividida em 4 grupos de 3 aluno(a)s - cada qual com uma função previamente planejada: medir, ler a direção e anotar as informações - e os grupos 


\section{E Eebates \\ em Educação Científica e Tecnológica \\ ISSN - 2236-2150 (Eletrônica)}

foram representados pelas cores da bandeira do RS - verde, amarelo, vermelho e branco. Cada grupo recebeu no ponto de partida - o portão social da escola - um envelope (da cor de sua equipe) contendo a primeira tarefa (deslocar-se tantos metros em uma dada direção). Todos os grupos estavam munidos de pranchetas com bloco e rascunho, caneta, calculadora, trena e bússola. Vale ressaltar que alguns dias antes realizamos, primeiro na sala de aula e depois na quadra, operações para aprenderem a usar os artefatos que necessitariam. De posse dos mesmos traçaram quadrados, retângulos, triângulos etc.

Após cumprirem cada etapa procuraram no entorno um novo envelope escondido e só poderiam pegar o envelope relativo à cor do seu grupo. No lado de fora de cada envelope havia uma xarada/pergunta ${ }^{20}$ e só abriram o envelope contendo as instruções para próxima etapa depois de responderem a xarada/pergunta. Ao todo, foram 6 envelopes, portanto seis operações, para cada grupo. Antes de abrirem o baú do tesouro (cada grupo encontrou o seu baú), uma tarefa comum a todos foi apresentarem quantos metros se deslocaram desde o ponto de partida até a chegada ao baú do tesouro, com isso estavam operando com números com representação decimal, visto que deveriam representa-los dessa forma para dar conta de quantos metros e centímetros se deslocaram por todo o circuito.

Dentro de cada baú havia, como tesouro, moedas de chocolate em embalagens douradas, sacos de balas coloridas, do tipo "gometes" ou "jujubas", ou como dizem por lá "gominhas" ou "balas de goma" e dois livros: O homem que

${ }_{20}$ Um exemplo de xarada/pergunta foi: Qual o nome do polígono que possui 5 lados? 
calculava $^{21}$, de Malba Tahan e $\mathrm{O}$ diabo dos números ${ }^{22}$, de $\underline{\text { Hans Magnus }}$ Enzensberger.

Se focarmos em nossos lastros epistemológicos e voltarmos ao Quadro 1, na Ação 7 - Adaptações de textos e encenações,- e na Ação 4 - Esquete do Malba Tahan, será possível observar que a escolha dessas duas obras fora intencional, com objetivos definidos e com propósito de resgate à cultura local, portanto, em sintonia com:

(i) os níveis de funcionamento da Atividade humana de Leontiev, ao permitir que desenvolvêssemos outras ações e operações;

(ii) com nossas premissas $\left(P_{2}\right),\left(P_{3}\right),\left(P_{4}\right),\left(P_{6}\right)$ e $\left(P_{7}\right)$;

(iii) com uma possível proposta de uma Educação etnomatemática, por voltarmo-nos para um ambiente onde procuramos "harmonizar sensações, sentimentos, razão e intuição na prática educativa, numa espécie de ecologia do ser/saber/fazer/conviver das diversidades culturais" (cf. SCANDIUZZI; LÜBEK, 2011, p.133);

(iv) Os princípios de interdisciplinaridade que adotamos, pois buscamos interação e dinamização, usufruindo os saberes das várias áreas do conhecimento, com interesses pedagógicos, científicos, socioambientais, culturais e humanos para com os seus envolvidos;

(v) com o pensamento etnomatemático, posto por Knijnik et I (2012, p. 18), ao interessarmo-nos em "examinar s práticas de fora da escola, associadas a racionalidades que não são idênticas à racionalidade que impera na Matemática

\footnotetext{
${ }^{21}$ MELO e SOUZA, Júlio César. O homem que calculava. São Paulo: Record, 2015 [1949].

22 ENZENSBERGER, Hans Magnus. O diabo dos números. Campinas: Companhia das Letras, 1998.
} 
escolar..." e não apenas pensarmos, mas por praticarmos "outras possibilidades para a Educação Matemática praticada na escola" (KNIJNIK et al, 2012, p.18).

No que se refere à caça ao tesouro, a intencionalidade foi, de forma lúdica, leva-lo(a)s a trabalhar com adição e multiplicação de números com representação decimal, na representação dos múltiplos e submúltiplos do metros. A ludicidade foi o aspecto motivacional, onde puderam colocar todas as fantasias peculiares à idade, tanto que vieram caracterizados de piratas, com lenços, brincos e tapa-olhos. A operacionalidade foi posta em um encontro antes da prática. Todo(a)s saberiam o que estava por vir, só não imaginavam que encontrariam um baú com "tesouros de verdade" (palavras de um(a) do(a)s participantes). Deixamos claro que o motivo de anotarem era para efetuarem a adição dos espaços percorridos, pois queríamos treinar o uso de calculadoras para adicionarem números com representação decimal e a necessidade foi o resgate à cultura local a partir da adaptação de trechos dos livros à cultura gaudéria, mas disso falaremos mais à frente. O baú do tesouro e sua existência foi o objeto que estimulou a ação, bem como suas respectivas operações, como motivo da ocorrência da mesma.

Como todos os grupos partiram da mesma origem (o portão social da escola), dois desses grupos possuíram uma das tarefas a ser executada em comum. Após se deslocarem à oeste, um trecho comum, a partir de certo ponto um iria à direção sul e o outro ao norte. Nesse trecho, comum aos dois grupos, os alunos deveriam medir a distância de $19,45 m$ na direção oeste. Lembramos que as trenas eram padronizadas e todas possuíam $5 \mathrm{~m}$ de comprimento.

Componentes do grupo Amarelo:

Ator 1 - Ande dezenove metros e quarenta e cinco centímetros a oeste.

Rodolfo - E como vocês pretendem executar essa tarefa? 
Ator 2 - Bah, é fácil! É só andar 3 vezes a medida da trena e depois marcar quatro metros e quarenta e cinco centímetros.

Componentes do grupo Branco

Ator 3 - Ande dezenove metros e quarenta e cinco centímetros a oeste.

Rodolfo - E como vocês pretendem executar essa tarefa?

Ator 4 - Olha só. Vou medir 4 vezes a medida da trena e depois tiro cinquenta e cinco centímetros.

Observemos que diante da mesma proposta, do mesmo texto (andar 19,45m na direção oeste) as estratégias dos grupos diferiram. Enquanto um optou operar pela falta (grupo Amarelo) o outro optou operar pelo excesso (grupo Branco), mas ambos realizaram a tarefa com primor. Mesmo assim, houve uma similaridade no que se refere à ideia de multiplicar - ou por 3 ou por 4 - ou seja, partiram do princípio de somas sucessivas que regem a operação de multiplicação por inteiros positivos.

Outras falas nos permitiram outras leituras, mas, de modo geral, observamos alguns critérios não muito usuais, como por exemplo, o de confiar mais no passo (um passo largo mede 1 metro) e no palmo (1 palmo equivale a $20 \mathrm{~cm}$ ) do que na trena. Isso ocorreu em um grupo (Grupo Verde), mais de uma vez - bastava haver discordância na leitura da trena. Observamos desse grupo é que o não hegemônico dá vez ao hegemônico toda vez que não há produção de conhecimento no que tange a sistematização de utilização de um instrumento. O mesmo aconteceu em relação o uso da calculadora (se houvesse resultados distintos, a abandonavam e passavam a contabilizar nos dedos). Em outras palavras, podemos dizer que há uma convergência para o fato de que os conhecimentos empíricos não são abandonados 
quando não realizam uma leitura plausível a respeito dos saberes acadêmicos (hegemônicos) trabalhados.

Também observamos que a Profe Vera estava sempre atenta às enunciações de seus alunos e aproveitava suas falas para provocar intencionalmente outras reações e pensares. Daí, comprovamos a premissa $\left(P_{5}\right)$ e quem produz significado não é o emissor, mas o receptor da enunciação. Levando o aluno a falar, com a devida atenção do professor na condução do processo, muitas novidades, não menos importantes ou educativas emergem. Vejamos que o foco não é o processo operatório somente; um algoritmo é tão-somente uma ferramenta para se trabalhar uma ideia, que é muito mais social do que meramente matemática. É disso que Chaves (2000, 2004, 2005, 2015) apontam como uma Matemática na ação, como uma possível forma ler o mundo.

Quando chegamos à partição dos livros não havia um livro para cada aluno, pois os mesmos foram adquiridos por nós [professore(a)s-pesquisadore(a)s]. Daí surgiu a ideia de fazermos uma sacola de leitura. O Programa PET Matemática rifou vários objetos (pen drive, calculadoras científicas, iPod, jogo de canetas, lapiseiras etc.) doados pelos alunos. Vendemos rifas para professores e estudantes do Departamento de Matemática (DEMAT) da UFSM e com a verba arrecadada compramos livros para todos os alunos da classe e mais 20 sacolas com os dois livros para circular entre as turmas da escola. Porém os livros da sacola de leitura chegaram à escola em novembro e durante o recesso escolar de julho os alunos se revezaram na distribuição dos livros que havia para a turma. A estratégia de distribuição foi sugerida pelos próprios alunos, moradores da zona rural. Eles se revezaram levando em consideração a proximidade das casas (coisa de, às vezes, 4 km de distância). Uma similaridade que observamos durante o processo, refere-se à 


\section{E Eebates \\ em Educação Científica e Tecnológica \\ ISSN - 2236-2150 (Eletrônica)}

disciplina dos atore(atrize)s. O prazo dado de leitura foi respeitado por todos e não houve negligenciamento na entrega do livro ao colega, na data estipulada.

\section{AlguMAS CONSIDERAÇÕES CONCLUSIVAS}

Fruto de nossas leituras, observações experiências e análises, observamos que, ao trabalharmos no viés proposto, passamos a compreender que, se por um lado a escola - de um modo geral - atua muito, por outro sistematiza pouco: há muita ação, mas - ainda - há pouca reflexão a respeito do que fazer e, principalmente do que foi feito se, quando e por que houve ou não alguma transformação nas práticas e vivências, quais as consequências dessas atividades.

Já a universidade teoriza muito, mas não coloca em prática, principalmente no que se refere às propostas de práticas pedagógicas voltadas à formação docente e à Educação Básica, o que acena para premissa $\left(P_{1}\right)$. Essa leitura, que entendemos ser global e plausível, nos direciona a enunciar que, trabalhar no viés proposto é um possível passo de transformação para que se trabalhe indissociavelmente a partir da tríade ensino, pesquisa e extensão em contraposição ao ETM - a partir da Teoria da Atividade, em uma perspectiva interdisciplinar, portanto, pautando-se pela dinâmica da produção de significado, com foco em uma educação etnomatemática (cf. NRP 7).

Em contrapartida, quando escola e universidade lançam-se a trabalho conjuntos visando a transformação dos quadros atuais de ensino, bem como de formação de professores, e ambas abrem-se a novas propostas metodológicas, pedagógicas, filosóficas e políticas, é possível rompermos com o modus operandi de uma educação oca, bancária e descontextualizada. Para tanto, é fundamental que ambas transvalorizem-se, desencastelem-se e negociem, não impondo suas verdades cristalizadas. Os programas PET e Pibid são exemplos disso e também 
exemplos de formas indissociáveis de ensino, pesquisa e extensão na área de Educação.

Essa perspectiva vai em direção ao que apresentamos na premissa $\left(P_{2}\right)$ apresentada por Patrick Geddes. Mas deparamo-nos com um problema: como fazer se não aprendemos isso em nossa formação como professores? Como quebrar com a inércia mantenedora do ETM? As sistemáticas adotadas - de ação que visa alcançar objetivos estabelecidos em grupo e que leva o indivíduo a desenvolver uma tarefa e a refletir sobre ela e sua prática (BALDINO; CARRERA DE SOUZA, 1997) e da (cf. NRP 7, 8 e 10) sistemática do conjunto de ações desenvolvidas pelo professor no ciclo de discussão em grupo sobre um problema (CHAVES, 2000, p.201) - nos mostraram que é possível romper com a burocratização que circunda as práticas de planejamentos escolas, sobretudo, no que se refere à introspecção do professor em criar (e não ou copiar) coletivamente.

No que tange a análise de similaridade apontamos que atore(atrize)s receberam bem a mudança de dinâmica da aula, tanto pelo fato da Profe Vera adotar uma prática diferenciada (de ouvi-lo(a)s, consulta-lo(a)s, seguir aquilo eu combinaram, realizar plenárias, diversificar nas metodologias de ensino e nas formas de medir e avaliar etc.) quanto pelo seu domínio não impositivo da classe, fruto de sua experiência e de sua concepções democráticas a respeito da dinâmica do processo de ensino. Um exemplo disso é que a cada nova proposta de ações Profe Vera dizia: "Vamos ver se eles compram a ideia".

Também houve a similaridade de os alunos estarem sempre dispostos e ansiosos por novas ações e operações conjuntas, dentro e fora da sala de aula.

Nossas (do(a)s professore(a)s-pesquisadore(a)s) leituras convergiram para as seguintes considerações: (i) o fato da escola - gestores, funcionários técnicoadministrativos e técnico-pedagógicos - estar aberta e receptível à nossa proposta 


\section{E Eebates \\ em Educação Científica e Tecnológica \\ ISSN - 2236-2150 (Eletrônica)}

foi fundamental às dinâmicas propostas; (ii) a coparticipação e interação das famílias foi fundamental, sobretudo no que se refere a motivação dos alunos; (iii) Mais propostas como essa, envolvendo como compartícipes escola e universidade deveriam ser mais valorizadas e mais frequentes, sobretudo nas escolas do campo; (iv) a perspectiva interdisciplinar é fundamental à formação integral e à valorização da cultura local; (v) Programas como PET e Pibid não podem ficar à mercê de políticas de governos, devendo ser frutos de políticas de Estado, sobretudo na área de formação de professores e propostas educacionais que envolvam universidade e escola.

Também entendemos que a experimentação, o lúdico, o artístico, assim como as enunciações, as narrativas, os modos próprios "de saber, de fazer e de conviver de cada cultura, para sua sobrevivência e transcendência" (SCANDIUZZI; LÜBECK, 2011, p.144) são fundamentais para que possamos ler o aluno no que se refere às suas expectativas, anseios, dúvidas e conhecimentos produzidos.

Trabalhar a partir da tríade proposta (Teoria da Atividade, MCS e uma proposta de uma possível Educação etnomatemática), a partir de uma perspectiva interdisciplinar, tomando como fundamentação as premissas apresentadas (cf. ( $\left.P_{1}\right)$ a $\left.\left(P_{8}\right)\right)$ e as ações diferenciais apresentadas nos moldes de Baldino \& Carrera (1997) (cf. NRP 7), bem como a dinâmica de grupo proposta em Chaves (2000, 2004, 2005) (cf. NRP 8) permitiu-nos não apenas romper com os dispositivos de sequestro do ETM, mas, principalmente, romper com os dispositivos mantenedores da inércia que leva ao fracasso do ensino de Matemática.

É importante deixarmos claro que as ações e operações apresentadas não excluem a necessidade de resolver exercícios, de trabalhar os conceitos matemáticos etc., mas nos apontou o quanto é importante que não nos limitemos à dinâmica do ETM. Não se trata de substituir um processo por outro, ou uma metodologia por 


\section{DE Eebates \\ em Educação Científica e Tecnológica \\ ISSN - 2236-2150 (Eletrônica)}

outras, mas de forma podemos repensar as nossas práticas para que possamos envolver os alunos nas perspectivas apresentadas.

\section{REFERÊNCIAS}

BALDINO, Roberto Ribeiro; CARRERA de SOUZA, Antonio Carlos. Grupo de PesquisaAção em Educação Matemática. In: RESUMO TÉCNICO: RELATÓRIO DO SISTEMA DIRETÓRIO DOS GRUPOS DE PESQUISA NO BRASIL, UNESP, IGCE, Rio Claro: CNPq, 1997.

BRASIL. Ministério da Educação. Secretaria de Educação Básica. Secretaria de Educação Continuada, Alfabetização, Diversidade e Inclusão. Secretaria de Educação Profissional e Tecnológica. Conselho Nacional da Educação. Câmara Nacional de Educação Básica. Diretoria de Currículos e Educação Integral. Diretrizes Curriculares Nacionais Gerais da Educação Básica. Brasília: MEC, SEB, DICEI, 2013.

BRASIL. Ministério da Educação e do Desporto, Instituto Nacional de Estudos e Pesquisas Educacionais. Parâmetros Curriculares Nacionais para o Ensino Fundamental: introdução. Brasília, 1998.

CEZAR, Mariana dos Santos; CHAVES, Rodolfo. A produção de significados matemáticos nos processos de ensino e aprendizagem na construção dos números reais. In: XII ENEM, 2016. São Paulo. Anais. p.1-12.

CHAVES, Rodolfo. (des)contínuos entre Modelo dos Campos Semânticos (MCS) e Etnomatemática. Plano de trabalho (Pós-doutorado) no PPG Mestrado em Educação Matemática e Ensino de Física. Área de concentração Educação Matemática, linha de pesquisa de Ensino e Aprendizagem da Matemática e seus fundamentos filosóficos, históricos e epistemológicos. Santa Maria: CCNE - UFSM, 2015.

CHAVES, Rodolfo. Material pedagógico na base nacional comum na linha da pedagogia da alternância: ensino de Matemática nas Escolas Família-Agrícolas. 


\section{DE Eebates \\ em Educação Cientifica e Tecnológica \\ ISSN - 2236-2150 (Eletrônica)}

Viçosa, MG: Departamento de Educação da UFV; Associação das Escolas FamíliaAgrícolas de MG, 2005.

CHAVES, Rodolfo. Por que anarquizar o ensino de Matemática intervindo em questões socioambientais? 223p. Tese (Doutorado em Educação Matemática) Programa de Pós-Graduação em Educação Matemática, Instituto de Geociências e Ciências Exatas de Rio Claro, Universidade Estadual Paulista, Rio Claro, 2004.

CHAVES, Rodolfo. Caminhos percorridos para a implantação do grupo de pesquisaação em educação matemática junto ao núcleo de ensino integrado de ciências e matemática da Universidade Federal de Viçosa. 285 p. (Dissertação de Mestrado em Educação Matemática) - Programa de Pós-Graduação em Educação Matemática, Instituto de Geociências e Ciências Exatas de Rio Claro, Universidade Estadual Paulista, Rio Claro, 2000.

FRANCISCO, Carlos Alberto. O Modelo dos Campos Semânticos como Instrumento de Leitura da Prática Profissional do Professor de Matemática. Disponível em < http://www2.rc.unesp.br/eventos/matematica/ebrapem2008/upload/306-1-Agt1_francisco_ta.pdf >. Acesso em 21/mar./2015.

GIL, A. C. Como elaborar projetos de pesquisa. 5. Ed. São Paulo: Atlas, 2010.

JAPIASSU, Hilton. Interdisciplinaridade e patologia do saber. Rio de Janeiro: Imago, 1976.

KNIJNIK, Gelsa; WANDERER, Fernanda; GIONCO, leda Maria; DUARTE, Claudia Glavam. Etnomatemática em movimento. Belo Horizonte: Autêntica, 2012. (Coleção Tendências em Educação Matemática).

KNIJNIK, Gelsa. Exclusão e Resistência: Educação Matemática e legitimidade cultural. Porto Alegre: Artes Médicas, 1996. 


\section{DE Eebates \\ em Educação Científica e Tecnológica \\ ISSN - 2236-2150 (Eletrônica)}

LEONTIEV, Alexis Nikolaevich. Actividad, conciencia y personalidade. México: Cartago, 1984.

LEONTIEV, Alexis Nikolaevich. O desenvolvimento do psiquismo. Lisboa: Horizonte Universitário, 1978.

LINS, Romulo Campos. O Modelo dos Campos Semânticos: estabelecimento e notas de teorizações. In: ANGELO, C. L. et al (org.). Modelo dos Campos Semânticos e Educação Matemática: 20 anos de história. São Paulo: Midiograf, 2012. p.11-30.

LINS, Romulo Campos. Por que discutir teoria do conhecimento é relevante para a Educação Matemática. In: BICUDO, M. A. V. (Org.). Pesquisa em Educação Matemática: concepções \& perspectivas. São Paulo: Editora UNESP, 1999. (Seminários DEBATES Unesp).

LINS, Romulo Campos; GIMENEZ, Joaquim. Perspectivas em aritmética e álgebra para o século XXI. 3. ed. Campinas: Papirus, 1997. (Perspectivas em Educação Matemática).

LINS, Romulo Campos. Epistemologia, História e Educação Matemática: tornando mais sólida as bases da pesquisa. Revista da Sociedade Brasileira de Educação Matemática - São Paulo, Ano 1, n. 1, set./1993, p.75-91.

LOURES, Marcela Andrade Martins; PINTO, Antonio Henrique. Tópico de Geometria Analítica em uma turma de EJA Ensino Médio: o cálculo da distância entre dois pontos. Vitória: Instituto Federal do Espírito Santo, 2015. (Série Guia Didático de Matemática - № 26).

MARTINS-SALANDIM, Maria Edneia. A interiorização dos cursos de Matemática no estado de São Paulo: um exame da década de 1960. Tese (Doutorado em Educação Matemática) - Programa de Pós-Graduação em Educação Matemática, Instituto de 


\section{E Debates \\ em Educação Científica e Tecnológica \\ ISSN - 2236-2150 (Eletrônica)}

Geociências e Ciências Exatas de Rio Claro, Universidade Estadual Paulista, Rio Claro, 2012.

MEURER, Ane Carine. Projeto PIBID Interdisciplinar do Campo. ([2009-2011] 2013). In: Proposta de Subprojeto, Edital N. 061/2013. Pró-Reitoria de Graduação, Programa Institucional de Bolsa de Iniciação à Docência - PIBID/UFSM.

NOVAIS, Ivonilton Pereira de. Dinâmica da produção de significado de construções pataxó por alunos de ensino médio em aula de campo. 169 f. Dissertação (Mestrado em Educação de Ciências e Matemática) - Programa de Pós-Graduação em Educação em Ciências e Matemática do Ifes. Vitória, 2017.

OLIVEIRA, Alex Jordane; SALAZAR, André Vicente; FONTAN, Emanuella Aparecida; COSME, Gerliane Martins; CADE, Márcia Brandão Santos; PAIVA, Maria Auxiliadora Vilela; FREITAS, Rony Cláudio de Oliveira. Medindo comprimentos e áreas. 2. Ed. In: CursosTécnicos PROEJA. Vitória: SETEC - Secretaria de Educação Profissional e Tecnológica; Grupo de Pesquisa PROEJA/CAPES/SETEC, 2009.

OLIVEIRA, Marta Kohl de. Vygotsky: aprendizado e desenvolvimento - um processo sócio-histórico. São Paulo: Scipione, 1997. (Pensamento e ação no magistério).

REISDOERFER, Carmen. Sobre as ações do Pibid/Matemática na constituição de saberes docentes de ex-bolsistas desse programa na Universidade Federal de Santa Maria. 185p. Dissertação (Mestrado acadêmico em Educação Matemática e Ensino de Física). Programa de Pós-Graduação em Educação Matemática e Ensino de Física, Universidade Federal de Santa Maria, Santa Maria, 2015.

SAD, Lígia Arantes. Cálculo Diferencial e Integral: uma abordagem epistemológica de alguns aspectos. Tese de Doutorado (em Educação Matemática). Programa de PósGraduação em Educação Matemática, Instituto de Geociências e Ciências Exatas de 
Rio Claro, Universidade Estadual Paulista, Rio Claro Universidade Estadual Paulista. Rio Claro, 1999.

SCANDIUZZI, Pedro Paulo; LÜBECK, Marcos. Itinerários do Grupo de Estudo e Pesquisa em Etnomatemática e sua Relação com a Educação Matemática. Boletim de Educação Matemática. V.25, n. 41, dez./2011, p.125-151.

SILVA, Amarildo Melchiades da; LINS, Romulo Campos. Sobre a dinâmica da produção de significados para a matemática. Jornal Internacional de Estudos em Educação Matemática. N.1, v.6 (2), 2013. Disponível em: $<$ http://periodicos.uniban.br/index.php?journal=JIEEM\&page=article\&op=view\&p ath[0]=373\&path[1]=395>. Acesso em: 12/jan./2014.

SILVA, Amarildo Melchiades da. Sobre a dinâmica da produção de significados para a matemática. Rio Claro. 2003. 147p. Tese (Doutorado em Educação Matemática) Programa de Pós-Graduação em Educação Matemática, Instituto de Geociências e Ciências Exatas de Rio Claro, Universidade Estadual Paulista.

Recebido em: Janeiro de 2017. Publicado em: Agosto de 2017. 